\title{
L'Inconstance punie: Anouilh and La Double Inconstance
}

\section{Deborah STREIFFORD-REISINGER}

7 The interpretation of a play occupies a substantial part of any critical analysis, but in the case of a play whose ending is 1 puzzling, the importance of interpretation increases dramatically. La Double Inconstance presents us with such a case: its contradictions continue to plague critics who debate the message of the play's ending. How should we interpret the love between Silvia and Arlequin? Do we witness the destruction of pure love by a manipulating force? Or are we instead to recognize the birth of mature love and realized identity? Unlike a novelist, who lacks no instrument to intervene as operator in his or her text, a playwright depends almost entirely on his or her characters to carry the staging. In La Double Inconstance, it is Flaminia who directs and manipulates the character-objects for the Prince, yet it is for the reader to interpret her actions. This interpretation implies a critique, one which is clearly biased by the reader's own experience. While this problem of reader response is interesting in and of itself, it is perhaps more revealing to study the interpretation of $L a$ 
Double Inconstance through another interpretation, that of Jean Anouilh. Anouilh's play, La Répétition ou l'amour puni, articulates an interpretation and thus a critique of Marivaux's play by staging parts of it within his own. Despite the striking similarities and interweaving of the two plays, very little has been written about them in relation to one another, and no one has attempted to redirect the focus of Anouilh toward Marivaux. I propose, then, to study La Double Inconstance as the tragedy that Anouilh perceived it to be, and then to interpret La Répétition as its contemporary conclusion.

To summarize Marivaux's play, two young lovers, Silvia and Arlequin, are torn apart, essentially abducted from their simple lives for the benefit of the Prince, who wishes to marry Silvia. With the help of Flaminia, his manipulating servant, the audience watches Silvia and Arlequin fall out of love, and alternately fall in love, with the Prince and Flaminia respectively. Marivaux subtitles his play "une comédie," a notation that serves to guide our reading. Knowing that the author intends his play to be a comedy and that Marivaux did in fact envision the end of his play as a happy ending of sorts, we feel in a sense relieved of our responsibility as readers/spectators, and we can comfortably applaud the final scene. However, in the silence that follows the final burst of applause, we may begin to doubt the author's intentions. After all, Marivaux often masks his characters in order to allow their "real" personality to shine through (Le jeu de l'amour, Les fausses confidences, etc.), and in the context of comedy, the masks affect a certain frivolity that lightens the characters' quest for identity. But hidden behind this light-heartedness, more recent critics have uncovered a profound psychology that de-masks the author himself. According to William Trapnell, for example, Marivaux often hid his real beliefs behind an "amateur mouthpiece" that would inspire confidence in the reader while at the same time dissolving the author. In this sense, Marivaux's plays are psychological, but because they don't seem to be, they remain subtle and thus affect a certain légereté that allowed Marivaux to please the public. If we push this assessment 
further, it follows that we may interpret the end of La Double Inconstance as yet another mask, behind which real identities are hidden and often lost. Thus the notation une comédie is a piège or a mask in and of itself. To further underline this idea, we can compare this notion of comedy to the traditional notion, in which a pure, first love triumphs against all odds. In La Double Inconstance, on the other hand, we witness the triumph, not of a new love, but of one that is constructed through the manipulation and destruction of that first, pure love. The possibility that this comedy is in fact a tragedy is highly debatable, but important nonetheless as it will help to uncover what, if anything, Marivaux is trying to tell us about love.

From the beginning of the first act, Marivaux depicts Silvia and Arlequin's love as pure, one whose innocence infers equality. Silvia's words to Flaminia attest to this equanimity; she states:

...qu'il me laisse mon pauvre Arlequin, qui n'est pas plus gros monsieur que je suis grosse dame, pas plus riche que moi, pas plus glorieux que moi, pas mieux logé; qui m'aime sans façon, que j'aime de même, et que je mourrai de chagrin de ne pas voir. (1.1 108)

She is truly happy to be poor, as long as she and Arlequin have each other. He, too, shares this feeling and rejects Trivelin's efforts to seduce him with riches. He states:

Vous êtes un grand nigaud, mon ami, de faire entrer Silvia en comparaison avec des meubles, un carrosse et des chevaux qui le traînent! Dites-moi, faiton autre chose dans sa maison que s'asseoir, prendre ses repas et se coucher? Eh bien! avec un bon lit, une bonne table, une douzaine de chaises de paille, ne suis-je pas bien meublé? (1.4 110)

This indirect critique of the court, indirect because Arlequin's character often speaks profoundly in spite of himself, places Arlequin together with Silvia and situates them outside of the complexities of a corrupt society. Nevertheless, the pure and against-all-odds nature of this love quickly becomes insecure in the face of power 
and corruption. ${ }^{1}$ It is only within the court that Silvia and Arlequin's love atrophies, in the hands of Flaminia's subtly manipulative powers. Thus all action and manipulation take place on stage, under her watchful eye (and our own).

In order to manipulate Silvia and Arlequin, however, Flaminia must first prove herself to be trustworthy. From the lovers' point of view, she is nothing but an adversary, someone who is helping the Prince to keep Silvia from her true love. But Flaminia's triumph lies in her ability to mask herself as a collaborator. She confirms Silvia's love for Arlequin: "je puis vous certifier sa tendresse." She calls them "mes amis," and she promises Silvia her fidelity: "on m'a mise auprès de vous; je ne vous desservirai point" (1. 6114$)$. By allowing the lovers to see each other and by sympathizing with their plight, which she, ironically, has made reality, she slips imperceptibly from one side to another, symbolic of power's diffuse nature.

The scenes that follow detail her work with each character, first attacking Silvia's vanity and her devoir de femme and then Arlequin's naive heart. Alternating from one character-object to the other, her pace lends a frenzy to the spectacle that demonstrates her great skill. Flaminia is able to alter their concept of reality and thus their understanding of their identities and emotions. What sets her apart from the other marivaudien manipulators is her way of masking herself while at the same time creating masks for others, a much more subtle, and in a sense, frightening game. In this way, she is able to work from the inside (with Silvia and Arlequin) from the outside (with the Prince and Trivelin) and from beyond, by manipulating the Prince and Trivelin as well. She proves to be an immensely effective stage director due to her rare combination of omnipotence and omnipresence.

The effectiveness and the power of Flaminia may also be explained by the delicacy of her game. To create a mask for someone is none other than to create a new identity, a necessary operation in the destruction of love. Flaminia divides Silvia and Arlequin's identities in order to allow her game to go on: she is able 
to make them ill at ease with themselves and thus incapable of judging their own love. With Arlequin, she knows that she must get his sympathy, as he is distrustful of women. She thus becomes a likable widow and transforms Arlequin into the double of her old lover:

Depuis que j'ai perdu mon amant, je n'ai eu de repos qu'en votre compagnie, je respire avec vous; vous lui ressemblez tant, que je crois quelquefois lui parler; je n'ai vu dans le monde que vous et lui de si aimables. (2.6 118)

Arlequin falls into this role of a double without his own knowledge, later declaring:

Je n'aurais jamais cru être si joli que vous le dites; mais puisque vous aimez tant ma copie, il faut bien que l'originel mérite quelque chose. (2.6 118)

He even believes himself to be the original rather than the copy that he represents. But Arlequin makes his own substitution as well. Since he cannot be with Silvia, he rationalizes, he should then be with Flaminia. He tells her, "quand je ne la vois point [Silvia], il n'y a qu'avec vous que je m'en passe" (2.6 118), thus making a direct exchange. Consequently he begins to love Flaminia as a friend and fellow conspirator, but he concludes by making a substitution for Silvia: in the end he loves no more than a mask.

Silvia also falls in love with someone who does not exist. Her identity, manipulated by Flaminia and the court ladies, becomes so fragile that she no longer knows if she loves Arlequin: "je l'aime; il le faut bien" and then later "je dois aimer Arlequin" (2.12 112). Her selfhood shattered, she suffers a veritable identity crisis, multiplied by the three men who love her: the Prince, the officer of the palace (who is really the Prince), and Arlequin. In the final episodes, when the Prince and the Officer become one, she discovers her identity. In the end, then, Silvia resolves her identity crisis by becoming her true self, which the Prince had already recognized as such. She is happy, as are the Prince, Flaminia, and Arlequin. 
Or at least this is how certain critics and many readers will explain it. Yet how can we find authenticity in someone so fickle and unknown to herself? Why did Sylvia require Flaminia's help? Why would she have fallen in love with Arlequin if she had already possessed internal authenticity? Finally, how can we know that she will not find her first identity again, or uncover another? This interpretation permits far too much doubt and is also too simplistic for an author such as Marivaux, who has perfected the jeu des masques. Nevertheless, whether we interpret the ending as happy, or the new love as a sham, it remains true that the original love between Silvia and Arlequin has somehow been corrupted. How else to interpret a series of lies designed to ruin a first love and create a new one? Jean Anouilh called the play " 1 'histoire élégante et gracieuse d'un crime" (La Répétition 36), thus deciphering it as the destruction of pure love, suffocated by the manipulation of identity through society. While Marivaux stages manipulation and disguise in his play, Anouilh stages several levels at once. A play within a play in the real sense of the word, La Répétition ou l'amour puni functions at the most delicate level of masking: by disguising themselves and putting on the Marivaux play, his characters reveal themselves in a way that allows us (and the characters) to seize a truth that could not otherwise be seen.

In the beginning of Marivaux's play, purity is presented as the love between Silvia and Arlequin, and at the end of the play, this love is destroyed. In La Répétition, a similar story takes place, but doubly complicated because, instead of withdrawing at the end of the Marivaux play, Anouilh's characters continue to act until there remains no hope for the existence of pure love. Unable to crawl out of their social strati, as Silvia and the Prince were able to do, Anouilh's characters go on to fight an impossible battle of social equality. The Count, who plays the Prince, forgets that his dramatic equivalent of Silvia (Lucile) has never had an Arlequin, and he becomes him. Thus finding himself stuck between the roles of the Prince and Arlequin, the Count is unable to free himself.

When the play opens, the characters enter the stage in Louis 
$\mathrm{XV}$ costumes, giving the impression that the play takes place in the 18th century. This first disguise accents the importance of masks and prepares the spectator for the play to come by situating the characters in their roles. The result will permit the characters to discover their real selves and their society masks, or both, as Hero and the Count are dismayed to discover. This difference announces the profundity of Anouilh while at the same time underlines his pessimism.

Contrary to La Double Inconstance, which begins with a mariage à faire (and à défaire), in La Répétition, there is no longer any respect for marriage. Anouilh shows us characters who cheat, lie, and shamelessly parade their lovers in front of their spouses. The lack of respect that the Count has for his marriage situates the state of love in this play: love has become an obstacle rather than an oasis. The count explains to his wife:

L'amour est le pain des pauvres, ne nous mettons pas, sur le tard, à pleurnicher l'un et l'autre au milieu de nos aubussons parce que nous ne l'avons pas connu. Il y a des choses mille fois plus importantes au monde que ce désordre inattendu. C'est comme une bouteille qu'on vide un soir, pour faire le fanfaron: on paie deux heures d'exaltation d'une longue nuit de migraine et de vomissements. C'est trop cher. (1 27)

This cynical statement characterizes each character of the play: the Count is frivolous, the Countess spoiled, and Hero is a drunk, misanthropic from love's disappointment. Only the innocent Lucile, the incarnation of purity, escapes the game, but she too is soon thrown into this satirical world.

The first part of Anouilh's play consists of the rehearsal and serves to situate the characters. The Count gives a ball during which his "friends" will stage La Double Inconstance. He chooses the roles and takes great pleasure in manipulating them to his advantage. He is soon surprised, however, to find himself a victim of his own game. To Lucile, he explains the role of Silvia: 
Silvia est une petite âme inaccessible qui le [le Prince] regarde à mille lieues et le trouble. Il y avait donc autre chose au monde que le plaisir- et il ne le savait pas?

(Sa voix a un peu changé malgré lui en parlant... Il conclut sourdement, comme gêné soudain) Mais je n'ai pas besoin de vous expliquer le rôle, Mademoiselle; vous n'avez qu'à être vous. (1 3738)

In one way, he gives her this identity, and in another, she is so well chosen for the role that there is really no difference. It is at this moment that he first desires her, and as they rehearse the Marivaux play (3.9 in La Double Inconstance), the stories intermix as representation becomes reality. ${ }^{2}$

The love that develops between the Count and Lucile suggests the purity of childhood, a familiar theme in Anouilh's work. ${ }^{3}$ Symbol of innocence, only love can recapture the simplicity so easily lost in the game of life. Once lost, Anouilh presents two choices: to follow the path of Hero, or to emulate the Count. Hero, like Arlequin, once had a pure love, but the Count persuaded him against the relationship. The explicit similarities between the Count and the Prince's behavior, and the comparison of Hero and Arlequin's first love experience evokes Marivaux and presents us with a frightening outcome to his play. Now a bitter drunk, Hero no longer has the will to live, and in the end, after violently attacking Lucile, he allows himself to be drawn into a duel that ends his life. The Count's path is no more favorable, however. He describes his life as a dandy:

Oui, j'ai été avenue du Bois faire les cent pas tous les jours à midi, mais $\mathrm{j}$ 'habitais à coté et tous mes amis le faisaient. Mais je n'étais pas tellement ridicule autant que je m'en souvienne... Enfin les filles de votre âge - à cette époque,- ne le trouvaient pas. (2 42)

As he admitted at the start of the play, he never felt the love that 
Hero had. Thus, the love between he and Lucile is pure and innocent, much like Hero's first love, or more aptly, like the love that they rehearse between Silvia and Arlequin. Against the world, they must struggle, but the Count assures Lucile that it poses no threat, and that they are "de tous petits rôles dans la pièce que nous allons jouer tous les deux" (2 64). At the end of this act, the curtain falls. We find ourselves at the end of the play, both the Marivaux play and the staged innocence: the real spectacle of Anouilh now begins.

The second part of La Repetition begins after the fall of the curtain (end of Act II and end of Marivaux play), which unmistakably represents the fall of purity: love is punished and the pièce rose becomes piece noire. If the first acts constitute a rehearsal of $L a$ Double Inconstance, the last three equal the reaction of the spectator-Anouilh. To mix the characters of Marivaux with real-life lends a dramatic sense to the play that underlines the finesse of the game: it is beautiful to watch on stage, but should not be played in the real world. Without their masks and the security of their roles, the Count and Lucile cannot survive. As much as the Count tries to distance himself from his universe, the world that created him, and that he likewise created, will not let him. Without him, the others cannot continue the game, and it is inconceivable to imagine a world where one lives happily without play, or game. For this reason, the Flaminia-like Countess, with the help of her marionettes, will destroy her Count's pure love.

In the intrigue that follows, Anouilh illustrates how love can be ruined just as easily as it is constructed. At the beginning of the play, there is no pure love, and at the end, it cannot exist. A theater of discovery that reveals others while at the same time revealing ourselves, Anouilh's play continues to speak to us today. Marivaux suggests that in playing the role of another, or in masking the self, a person might better discover his/her identity. Anouilh, however, shows the dire consequences of these masks, for when the Count and Lucile play at acting, they enter into an uncertain game. The disguise reveals a certain truth, but also gives a false confidence. Outside of the stage, life is different, and it is difficult to struggle 
on the side of purity. John Harvey explains this dilemma as the existence of two sides of life, between which there exists a conflict. The compromise is purity: one can accept life, play the game, and make compromises, or one may refuse life and demand a pure ideal. Marivaux makes a veiled allusion to this in his plays, but Anouilh thoroughly exposes this certainty. Purity has now become boring and difficult, while reality and compromise have come to equal wisdom. With everything turned in derision, neither one nor the other can triumph. In La Répétition, Anouilh responds to Marivaux and to his own era. Two centuries later, with actors who are thirty years older, his characters protest to have taken a wrong turn. Hero no longer has his Evangeline, and the Count is no longer a young dandy. Society itself has become a game too complicated to escape, and yet it remains somehow meaningless. As the Count explains to his wife:

Le naturel, le vrai, celui du thé,tre, est la chose la moins naturelle du monde, ma chËre. N'allez pas croire qu'il suffit de retrouver le ton de la vie. D'abord, dans la vie le texte est toujours si mauvais! (2 46-47)

University of North Carolina 


\section{Notes}

1 There are, for instance, events that carry the potential to stifle the characters' love outside of the staging of the play, but they prove to be harmless in and of themselves. Silvia's attraction to the Prince, whom she does not know to be the Prince, and Arlequin's love of good food are mere minor flaws in their lives.

2 Anouilh's expertise presents itself clearly in this second act which balances the characters and the language of each representation taking place. He brilliantly manipulates the marivaudage and renders almost impossible the distinction of the Marivaux play from his own.

3 Lucile even serves as a direct link to youth, both because of her age and her work with children, but the Count is far from youthfulness. He tries to separate himself from Lucile by this difference ("à l'époque de mon premier melon, vous vagissiez dans vos couches, ma petite fille" [2 42$]$ ), but she only pities him for having lost his innocence. 


\section{Works Cited}

Anouilh, Jean. La Répétition ou l'amour puni. Paris: Larousse, 1950.

Harvey, John. Anouilh: Study in Poetics. New Haven: Yale Press, 1964.

Marivaux. La Double Inconstance. 1723. Théâtre complet. Paris: Editions Seuil, 1964.

Trapnell, William. "Identité et sympathie chez Marivaux." Marivaux d'hier Marivaux d'aujourd'hui. Eds. H. Coulet et J. Ehrard. Paris: Editions du Centre National de la Recherche Scientifique, 1991. 

